\title{
The development and validation of a single SNaPshot multiplex for tiger species and subspecies identification-Implications for forensic purposes
}

\author{
Thitika Kitpipit ${ }^{\mathrm{a}, \mathrm{e}}$, Shanan S. Tobe ${ }^{\mathrm{a}}$, Andrew C. Kitchener ${ }^{\mathrm{b}, \mathrm{c}}$, Peter Gill ${ }^{\mathrm{a}, \mathrm{d}}$, Adrian Linacre ${ }^{\mathrm{e}, *}$ \\ ${ }^{a}$ Centre of Forensic Science, WestChem, Department of Pure and Applied Chemistry, University of Strathclyde, Glasgow, G1 1XW, United Kingdom \\ ${ }^{\mathrm{b}}$ Department of Natural Sciences, National Museums Scotland, Edinburgh EH1 1JF, United Kingdom \\ ${ }^{\mathrm{c}}$ Institute of Geography, School of Geosciences, University of Edinburgh, Edinburgh, EH8 9XP, United Kingdom \\ ${ }^{\mathrm{d}}$ Institute of Legal Medicine, University of Oslo, Norway \\ e School of Biological Sciences, Flinders University, Adelaide 5001, South Australia, Australia
}

\section{A R T I C L E I N F O}

Article history:

Received 17 December 2010

Received in revised form 22 February 2011

Accepted 1 June 2011

\section{Keywords:}

Mitochondrial DNA

SNP

SNaPshot multiplex kit

Tiger species

Subspecies

\begin{abstract}
A B S T R A C T
The tiger (Panthera tigris) is currently listed on Appendix I of the Convention on the International Trade in Endangered Species of Wild Fauna and Flora; this affords it the highest level of international protection. To aid in the investigation of alleged illegal trade in tiger body parts and derivatives, molecular approaches have been developed to identify biological material as being of tiger in origin. Some countries also require knowledge of the exact tiger subspecies present in order to prosecute anyone alleged to be trading in tiger products. In this study we aimed to develop and validate a reliable single assay to identify tiger species and subspecies simultaneously; this test is based on identification of single nucleotide polymorphisms (SNPs) within the tiger mitochondrial genome. The mitochondrial DNA sequence from four of the five extant putative tiger subspecies that currently exist in the wild were obtained and combined with DNA sequence data from 492 tiger and 349 other mammalian species available on GenBank. From the sequence data a total of 11 SNP loci were identified as suitable for further analyses. Five SNPs were species-specific for tiger and six amplify one of the tiger subspecies-specific SNPs, three of which were specific to P.t. sumatrae and the other three were specific to P. t. tigris. The multiplex assay was able to reliably identify 15 voucher tiger samples. The sensitivity of the test was 15,000 mitochondrial DNA copies (approximately $0.26 \mathrm{pg}$ ), indicating that it will work on trace amounts of tissue, bone or hair samples. This simple test will add to the DNA-based methods currently being used to identify the presence of tiger within mixed samples.
\end{abstract}

(C) 2011 Elsevier Ireland Ltd. All rights reserved.

\section{Introduction}

Tigers once had a widespread geographical distribution, including southern and eastern Asia, ranging as far north as the Russian Far East to as far south as the Sunda Islands [1,2], and had an estimated population size of 100,000 in 1900 [2,3]. Owing to habitat loss and hunting/poaching, tiger populations are presently only a fraction of their previous size; recent estimates suggest there are only approximately 3200 wild tigers [4-8]. Up to nine subspecies of tiger are currently recognized: Panthera tigris altica, P. t. amoyensis, P. t. tigris, P. t. corbetti, P. t. sumatrae, P. t. virgata, $P$. $t$. sondaica, P. t. balica and P. t. "jacksoni" (N.B. This taxon is a nomen nudum, and if valid awaits a formal scientific description) [9]. Three of these putative subspecies are now extinct (P. t. virgata, $P$. $t$. sondaica, and P. t. balica) and P. t. amoyensis is no longer present in the wild and exists only in captivity [10], although it has been

\footnotetext{
* Corresponding author. Tel.: +61 82012465; fax: +61 82013015.

E-mail address: adrian.linacre@flinders.edu.au (A. Linacre).
}

suggested recently that even these are subspecific hybrids with P. $t$. corbetti [11]. The remaining five extant tiger subspecies are critically endangered [5]; however there is a continuing discussion as to how many tiger subspecies can be recognized based on morphological, biochemical, and molecular genetic studies with different authors proposing diverse conclusions [11-14]. For the purposes of this study we assume that five existing tiger subspecies survive, with no further judgment on their taxonomic validity. As the subspecies P.t. amoyensis is no longer present in the wild, only the remaining four subspecies are likely to be poached from wild populations and are the focus of this report.

There are several governmental and charitable organizations that regularly produce reports on illegal wildlife trade [15-17]. Extreme poaching and the illegal trade in tiger skins and body parts are important factors in these reports and significantly contribute to the decline in the number of wild tigers [18] and is evident in surveys carried out by organizations such as TRAFFIC [19]. This has escalated to such an extent that tiger 'farms' have been proposed to breed tigers for commercial use of their parts [20]. Tiger parts are used in traditional Oriental medicine without any scientific

1872-4973/\$ - see front matter (c) 2011 Elsevier Ireland Ltd. All rights reserved. doi:10.1016/j.fsigen.2011.06.001 
support for a therapeutic effect. For example, tiger bone is used in Asian folk remedies or Traditional Chinese Medicine (TCM), and is normally mixed with materials derived from other animal species or herbal material for a compound recipe [21]. Tiger body parts, such as tail, whisker and eyeball, are also claimed to have medicinal properties [22]. Tiger skins are highly sought after as house and costume decoration in some countries such as Tibet [23]. All of these uses of tiger parts have resulted in a highly profitable market in many countries.

All five extant tiger subspecies are listed currently on CITES (Convention on International Trade in Endangered Species) Appendix I, which affords them protection at the highest level from international trade. All are on the International Union for the Conservation of Nature's Red List as Critically Endangered. International trade in tigers and tiger body parts is prohibited by signatories to CITES and many countries have national legislation preventing the ownership of tiger body parts. The role of a forensic science laboratory is to determine if seized material contains even traces of species for which trade is prohibited by CITES agreements or national legislation. Morphological features may aid in the identification of tiger skins and bones, but not their subspecies [24]. Recognizable parts are not present in many commercially available medicines and other products derived from the tiger. To aid in the prevention of trade in tigers and their parts, a molecular approach may be used to ensure whether or not examined samples contain tiger DNA. Owing to the potential for degradation of samples found in a forensic context, nuclear DNA is unlikely to yield results and, therefore, mitochondrial DNA may be used as an alternative means of species identification.

The use of genetic markers for tiger species identification has been previously reported using a number of different detection methods. These approaches employ traditional PCR amplification, using tiger species-specific primers designed for mitochondrial loci such as: cytochrome $b$ (cyt $b$ ); NADH; cytochrome oxidase I (COI) and II (COII); 12s rRNA; and the control region [11,25-27]; RFLPPCR [28]; and real-time PCR, using species-specific ARMs [29]. However, none of these techniques is able to distinguish between subspecies, and neither can they accurately assign an individual to a particular population. The use of single nucleotide polymorphisms (SNPs) has been used to try and separate tiger subspecies, but was never developed into a full functional or validated forensic test [11]. SNPs have been used in forensic wildlife investigations to identify a number of other protected or endangered wildlife species [30,31], including plants [32]. One of the major challenges of determining the presence of tiger in medicines is their very small quantities, which may have been pre-treated by various methods thus yielding trace quantities of potentially highly degraded DNA.

In this study we report on the identification of tiger-specific SNP haplotypes within the tiger mitochondrial genome, which can also be used to distinguish between two particular tiger subspecies. These SNP loci are the basis for a single multiplex SNaPshot assay. The development and validation of the assay is also demonstrated.

\section{Materials and methods}

\subsection{Sample collection}

Fifteen voucher tiger samples were obtained from the National Museums Scotland, Edinburgh Zoo, Dudley Zoo, Isle of Wight Zoo, and Auchingarrich Wildlife Park, all in the UK. These samples comprised hair and tissues from different and unrelated individual tigers. Of these samples, four samples were identified previously as P. t. sumatrae, four were from P. t. tigris, five samples were from P. t. altaica, and two samples were from P. t. corbetti. Hair samples were plucked randomly from the individual's body skin and then stored in a sterile bag. Sterile buccal swabs were used to collect forensically appropriate samples from muscle and other tissues. The hair was stored at room temperature and the swabs were stored at $-20^{\circ} \mathrm{C}$ until extraction.

\subsection{DNA extraction}

DNA was extracted using QIAamp DNA Mini Kit (QIAGEN, Crawley, UK), according to the manufacturer's protocols for the relevant sample type. The DNA extracts were stored at $-20{ }^{\circ} \mathrm{C}$ for further analysis.

\subsection{The identification of tiger species- and subspecies-specific SNPS}

\subsubsection{Tiger subspecies-specific SNP identification}

The mitochondrial genome was sequenced for 8 tiger samples, comprising two from each of four subspecies. These new data were combined with 492 registered $P$. tigris sequences available on GenBank (www.ncbi.nih.gov). Five hundred and forty-four putative tiger DNA sequences were available although 52 sequences were not used as these data were incomplete or otherwise unsuitable. The remaining 492 DNA sequences were aligned using Clustal X2 [33] to confirm the authenticity of the tiger DNA sequences and minimize the potential for errors in the DNA sequence. The accession numbers, and other relevant information, for these eight new DNA sequences and the 492 DNA tiger sequences retrieved from GenBank data are shown in Table 1. DNA-sequence variability between tiger subspecies over the entire mitochondrial genome was determined. Any SNPs that were specific to a particular tiger subspecies were identified and recorded.

\subsubsection{Tiger species-specific SNP identification}

To examine tiger-species specific SNPs, 349 DNA sequences of the cyt $b$ gene from mammalian species spanning a wide range of taxonomic groups were aligned with 71 tiger sequences, which included all five extant tiger subspecies. A list of mammalian species and their GenBank accession numbers are shown in the supplementary Table S1. These 420 DNA sequences were aligned using Clustal X2. A haplotype of the five SNPs was identified that is specific for all tiger subspecies and not present in other mammalian species. Within the haplotype it should be noted that other mammalian species share one or more of the SNPs with tiger subspecies, but no other species had all five.

\subsection{Detection of tiger species and subspecies by SNaPshot assay}

\subsubsection{The multiplex of SNaPshot template amplification}

After the tiger species- and subspecies-specific SNPs were identified, three primer pairs (P1, P2 and P3) were designed to amplify mitochondrial regions that included these SNPs. The physical parameters and secondary structure of the primers were checked using the same tools as primers for the amplification of an entire tiger mitochondrial genome as described previously [34]. The sequences of these three primer sets from $5^{\prime}$ to $3^{\prime}$ are: P1F ACTCAGGACAATGAACCGT; P1R TAAGTAGTGCTGTTATGGCTAGTAG-TG; P2F ATCAACTCCATTAAACGTCTCTT; P2R GGAAGATGAGGTTGAGGTTG; P3F TTTGGCTCCTTACTAGGGGT; and P3R TTGGCGGGGATGTAGTT. The multiplex PCR amplifications were performed in a total volume of $20 \mu \mathrm{L}$, containing $200 \mu \mathrm{M}$ of each dNTP, $1 \times$ PCR buffer (10 mM Tris-HCl, pH 8.3, $50 \mathrm{mM} \mathrm{KCl}$ ), $2.0 \mathrm{mM}$ $\mathrm{MgCl}_{2}, 2.0$ units Platinum Taq polymerase (Invitrogen, Paisley, UK), $0.5 \mu \mathrm{M}$ of primer P1 and P3, $1 \mu \mathrm{M}$ of primer P2, and sterile water. The PCRs were conducted using a 2720 Applied Biosystems thermal cycler. Amplification conditions for these primers were as follows: 35 cycles of denaturation at $95{ }^{\circ} \mathrm{C}$ for $45 \mathrm{~s}$, annealing at 
Table 1

Tiger DNA sequence information used in this study, including: accession number, total number of DNA sequences used, author of relevant paper, the year published.

\begin{tabular}{|c|c|c|c|}
\hline Accession number & No. & Author, year & MtGene \\
\hline JF357967-JF357974 & 8 & Kitpipit et al., 2011 & Complete mitochondrial genomes \\
\hline EU661609-EU661691, FJ228452 & 84 & Mondol, 2009 & ND2, ND5, cyt $b, \mathrm{CR}$ \\
\hline EU527874-EU527859 & 16 & Sharma, 2009 & 12S rRNA, ND2, ND5, cyt $b$ \\
\hline FJ403464.1-67.1 & 4 & Matrai, 2009 & cyt $b, \mathrm{CR}$ \\
\hline FJ895266.1 & 1 & Yoo, 2009 & cyt $b$ \\
\hline FN257739.1, FM999724.1 & 2 & Doung/Din, 2009 & ND2, cyt $b$ \\
\hline $\begin{array}{l}\text { FJ469625.2, FJ694967.1-972.1, } \\
\text { FJ461529.2-534.2, FJ608583.1-585.1 }\end{array}$ & 16 & Shi and Zhang, 2009 & COI, COIII, ND4 \\
\hline EU395630.1-645.1 & 16 & Khan et al., 2009 & ND5 \\
\hline EU184702-EU184691 & 12 & Ryan, 2008 & cyt $b$ \\
\hline $\begin{array}{l}\text { FJ422145.1, FJ465508.1-511.1, } \\
\text { FJ478155.1-158.1, FJ455122.1-125.1 }\end{array}$ & 13 & Shi and Zhang, 2008 & COI, COIII, CR \\
\hline FM179470-71.1 & 2 & Nagappa et al., 2008 & 12S rRNA \\
\hline FJ185309.1 & 1 & Ghosh et al., 2008 & $\mathrm{COI}$ \\
\hline EF375881.1 & 1 & Rajput and Goyal, 2007 & ND1 \\
\hline AB211408-11 & 4 & Sugimoto et al., 2006 & cyt $b$ \\
\hline EF179376-EF179357 & 20 & Ryan, 2006 & cyt $b$ \\
\hline AB193164.1 & 1 & Nagata, 2006 & cyt $b$ \\
\hline $\begin{array}{l}\text { AY452097-99.1, AY452101, } \\
\quad \text { AY452111.1, 112.1,114.1-119.1 }\end{array}$ & 12 & Zhang et al., 2006 & ND5, CR \\
\hline DQ111950-51.1 & 2 & Wei et al., 2005 & ND5 \\
\hline AY736559-AY736808 & 250 & Luo et al., 2004 & 12S rRNA, ND1, ND2, COI, ND5, ND6, cyt $b, \mathrm{CR}$ \\
\hline AY452110.1 & 1 & Zhang et al., 2003 & 16S rRNA \\
\hline AF053018-AF053051 & 34 & Cracraft, 1998 & cyt $b$ \\
\hline Total tiger sequences & 500 & & \\
\hline
\end{tabular}

$60{ }^{\circ} \mathrm{C}$ for $45 \mathrm{~s}$, extension at $72{ }^{\circ} \mathrm{C}$ for $1 \mathrm{~min} 30 \mathrm{~s}$, and a final extension at $72{ }^{\circ} \mathrm{C}$ for $20 \mathrm{~min}$. The reaction was then held at $4{ }^{\circ} \mathrm{C}$. From the final PCR, $2 \mu \mathrm{L}$ were run on a $3 \%$ agarose gel to ensure that the amplifications were successful and provided all the expected fragments. The remainder of the PCR products were then purified using the QIAquick PCR purification kit (QIAGEN), following the manufacturer's protocol.

\subsubsection{SNaPshot reaction and product analysis}

Eleven SNaPshot extension primers were designed to bind adjacent to the SNPs either in the forward or in the reverse direction (Table 2). The SNaPshot primers were examined for their physical parameters and secondary structure as described previously [34]. Different-length tails (poly GACT) were added to the $5^{\prime}$ end of the primers to vary the primer sizes from 20 to $70 \mathrm{bp}$. The singleplex and multiplex SNaPshot reactions were performed using the SNaPshot multiplex kit (Applied Biosystems, Foster City, CA, USA) in a total volume of $10 \mu \mathrm{L}$, containing $5 \mu \mathrm{L}$ reaction mix, $3 \mu \mathrm{L}$ multiplex template, $1 \mu \mathrm{L}$ sterile water, and $1 \mu$ L extension primer mix. For the singleplex reactions $0.2 \mu \mathrm{M}$ of each extension primer was added, and the optimal concentrations of each primer added in the multiplex reaction are shown in Table 2. The SNaPshot PCRs were amplified in a 2720 Applied Biosystems thermal cycler using the following conditions: 25 cycles of $96{ }^{\circ} \mathrm{C}$ for $10 \mathrm{~s}, 50{ }^{\circ} \mathrm{C}$ for $5 \mathrm{~s}$, and $60{ }^{\circ} \mathrm{C}$ for $30 \mathrm{~s}$. SNaPshot products were then purified by Shrimp
Alkaline Phosphatase (SAP) to remove unincorporated ddNTPs and primers, by adding 1 unit of SAP into the SNaPshot reaction mixtures. The mixture was incubated at $37^{\circ} \mathrm{C}$ for $60 \mathrm{~min}$ and then $75{ }^{\circ} \mathrm{C}$ for $15 \mathrm{~min}$ to deactivate the enzyme.

From the SNaPshot-purified products, $2 \mu \mathrm{L}$ were mixed with $15.5 \mu \mathrm{L}$ of formamide and $0.5 \mu \mathrm{L}$ of GeneScan-120 LIZ size standard (Applied Biosystems). The formamide mix was heated at $95{ }^{\circ} \mathrm{C}$ for 3 min and stored at $4{ }^{\circ} \mathrm{C}$ until ready for further analysis. The extended products were separated by capillary electrophoresis using the ABI Prism 310 Genetic Analyzer (Applied Biosystems), with a $36-\mathrm{cm}$ length capillary and POP-4 polymer. The SNP typing results were analyzed using GeneMapper version 3.2.1.

\subsection{The validation of the developed SNaPshot multiplex assay for tiger species and subspecies identification}

The SNaPshot multiplex assay for tiger species and subspecies identification was validated for accuracy, sensitivity, specificity and blind-trial tests. The assay was used to analyze 15 tiger samples described in the sample collection method. Ten of fifteen voucher tiger samples were picked at random. Data were collected by using aliquots of the same PCR product which was injected onto the capillary 10 times to determine run variation. The average range and size of the fragments, and their standard deviation were calculated for all SNP peaks. For the sensitivity test, the P. t. corbetti

Table 2

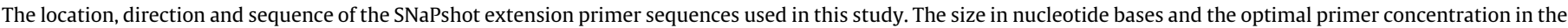
SNaPshot multiplex are also shown.

\begin{tabular}{|c|c|c|c|c|}
\hline Position & Strand direction & Single based extension primer sequence (5-3) & Primer size (nucleotides) & [Opt.] $(\mu \mathrm{M})$ \\
\hline Tiger-15154 & Forward & TTTGGCTCCTTACTAGGGGT & 20 & 0.10 \\
\hline Tiger-15268 & Reverse & gaTTGGCATGTAGATATCGGATAAT & 25 & 0.50 \\
\hline Tiger-15385 & Reverse & tgactgacTGACCGTAAACAATAGCACAAT & 30 & 0.50 \\
\hline Tiger-15391 & Forward & tgactgactgactAAACATGAAATATCGGGATTGT & 35 & 0.20 \\
\hline Tiger-15673 & Forward & gactgactgactgactgactAATAACCCCTCAGGAATGGT & 40 & 0.15 \\
\hline TIG-5050 & Forward & actgactgactgactgactgactAATGAACCGTATCAAAAGACCT & 45 & 0.20 \\
\hline TIG-5533 & Forward & actgactgactgactgactgactgacTATCCTACTGCTAATAATATCTCT & 50 & 0.20 \\
\hline TIG-14618 & Reverse & ctgactgactgactgactgactgactgactgactACCCGCACCATTAAACTTAAA & 55 & 0.30 \\
\hline SUM-5608 & Reverse & tgactgactgactgactgactgactgactgactTGTTATGGCTAGTAGTGTGGGTATTAT & 60 & 0.12 \\
\hline SUM-15223 & Forward & tgactgactgactgactgactgactgactgactgactgactgactACATCAGACACAATAACCGC & 65 & 0.40 \\
\hline SUM-15743 & Reverse & actgactgactgactgactgactgactgactgactgactgactgactGACGAGTAGTRTGAGGGTTAGGA & 70 & 1.00 \\
\hline
\end{tabular}


DNA was firstly quantified following the method described in [35] where copy number of mitochondrial DNA was obtained. This quantified tiger sample, with a starting concentration of 120,000 mitochondrial copies (equating to $2.06 \mathrm{pg}$ ) per $\mu \mathrm{L}$, was used to make a two-fold serial dilution for 5 concentrations, 120,000 , $60,000,30,000,15,000$, and 7500 mitochondrial copies/ $\mu \mathrm{L}$. These serial dilutions were then analyzed by the developed assay. Fourteen other mammalian species were used to test the specificity of the assay. These mammalian species were cheetah (Acinonyx jubatus), jaguar (Panthera onca), lion (Panthera leo), leopard (Panthera pardus), clouded leopard (Neofelis nebulosa), puma (Puma concolor), domestic cat (Felis catus), bear (Ursus thibetanus), horse (Equus caballus), sika deer (Cervus nippon), domestic dog (Canis familiaris), cow (Bos taurus), goat (Capra hircus) and human (Homo sapiens). For the blind-trial test, 10 tiger and other mammalian samples were randomly picked from a total of 293 samples. Of these 293 samples, 250 samples are voucher nonPanthera mammalian DNA from 20 mammalian species, 15 samples are one of four tiger subspecies DNA, and 28 samples are voucher big cat DNA from 7 big cat species. The 10 blind samples were then analyzed by the developed SNaPshot assay.

\section{Results and discussion}

\subsection{Tiger species- and subspecies-specific SNPs}

The complete genome of eight tiger species was sequenced and the sequences registered with GenBank (Table 1). From a search of entire tiger mitochondrial genomes, a total of six tiger subspeciesspecific SNPs were identified in three mitochondrial gene loci: ND2, ND6, and cyt $b$. Three of the six SNPs are specific to P. t. sumatrae and the rest are specific to P. t. tigris. SNPs specific to P. t. altaica or P. $t$. corbetti could not be identified over the entire mitochondrial genome. The position and location of SNPs on the mitochondrial genome are shown in Table 3. With the exception of the SNP at position 15223, the tiger species-specific SNPs are transition variants, which is consistent with nucleotide base substitutions biased in favor of transitions rather than transversions. Five of six

Table 3

Subspecies specific SNPs (shown in bold) for the tiger, with their position and location on the mitochondrial genome.

\begin{tabular}{|c|c|c|c|c|c|c|}
\hline \multirow{2}{*}{$\begin{array}{l}\text { mtlocus } \\
\text { Position } / 17009^{\mathrm{a}}\end{array}$} & \multicolumn{3}{|l|}{ ND2 } & \multirow{2}{*}{$\begin{array}{l}\text { ND6 } \\
14618\end{array}$} & \multicolumn{2}{|l|}{ cyt $b$} \\
\hline & 5050 & 5533 & 5608 & & 15223 & 15743 \\
\hline P. t. altaica & C (3) & G (3) & $C(3)$ & $C(3)$ & $\mathrm{T}(20)$ & A (17) \\
\hline P. t. tigris & $\mathbf{T}(29)$ & $\mathbf{A}(8)$ & $C(8)$ & $\mathbf{T}(8)$ & $\mathrm{T}(10)$ & $A(38)$ \\
\hline P.t. sumatrae & $C(10)$ & G (10) & $\mathbf{T}(10)$ & $C(10)$ & $\mathbf{A}(11)$ & G (19) \\
\hline P. t. amoy & $C(1)$ & $G(1)$ & $C(1)$ & $C(1)$ & $\mathrm{T}(1)$ & $A(1)$ \\
\hline P. t. corbetti & $C(11)$ & $G(12)$ & $C(12)$ & $C(11)$ & $\mathrm{T}(38)$ & $A(15)$ \\
\hline
\end{tabular}

The number inside bracket is a number of tiger sequences used for the alignment.

a The position was determined by aligning tiger sequences with the cat sequences accession number U20753.

Table 4

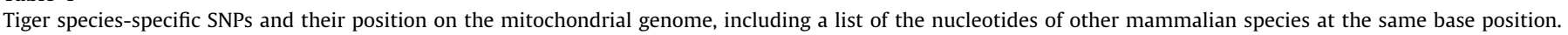

\begin{tabular}{|c|c|c|c|c|c|}
\hline Position/17009a & 15154 & 15268 & 15385 & 15391 & 15673 \\
\hline Panthera tigris (Tiger) & G (43) & G (44) & G (69) & G (69) & $G(70)$ \\
\hline Melursus ursinus (Sloth bear) &.$(2)$ & $A(2)$ & $C(2)$ & $\mathrm{T}(2)$ & $A(2)$ \\
\hline Ursus maritimus (Polar bear) & . (1) & $A(1)$ & $C(1)$ & $\mathrm{T}(1)$ & $A(1)$ \\
\hline Ursus arctos (Brown bear) &.$(3)$ & $A(3)$ & $C(3)$ & $\mathrm{T}(3)$ & $A(3)$ \\
\hline Crossarchus obscurus (Long-nosed cusimanse) & . (2) & $A(2)$ & $A(2)$ & $A(2)$ & $A(2)$ \\
\hline Panthera onca (Jaguar) & . (2) & $A(2)$ & $A(2)$ & $A(2)$ & $A(2)$ \\
\hline Panthera onca (Jaguar) & . (1) & $A(1)$ & - & - & - \\
\hline Ovibos moschatus (Muskox) & $C(4)$ & $A(4)$ &.$(4)$ & $\mathrm{T}(4)$ & A (4) \\
\hline Tremarctos ornatus (Spectacled bear) & (1) & $A(1)$ & $A(1)$ & $\mathrm{T}(1)$ & $A(1)$ \\
\hline Ailuropoda melanoleuca (Giant panda) &.$(3)$ & $A(3)$ & $A(3)$ & $\mathrm{T}(3)$ & $A(3)$ \\
\hline Marmota caligata (Hoary marmot) & $A(3)$ & $A(3)$ &.$(3)$ & $\mathrm{T}(3)$ & $C(3)$ \\
\hline Erignathus barbatus (Bearded seal) & $C(3)$ & $A(3)$ & $C(3)$ & $C(3)$ & . (3) \\
\hline Fossa fossana (Malagasy civet) & $A(2)$ & $A(2)$ &.$(2)$ & $\mathrm{T}(2)$ & $A(2)$ \\
\hline Herpestes naso (Long-nosed mongoose) & $A(2)$ & $A(2)$ & $A(2)$ & $C(2)$ &.$(2)$ \\
\hline Mungos mungo (Banded mongoose) & $A(2)$ & $A(2)$ &.$(2)$ & $C(2)$ & $A(2)$ \\
\hline Civettictis civetta (African civet) & $C(2)$ & $A(2)$ & $A(2)$ & $A(2)$ &.$(2)$ \\
\hline Martes zibellina (Sable) & $C(2)$ &.$(2)$ & $\mathrm{T}(2)$ & $C(2)$ & $C(2)$ \\
\hline Microtus maximowiczii (Maximowicz's vole) & $C(1)$ & $A(1)$ &.$(1)$ & $C(1)$ & $\mathrm{T}(1)$ \\
\hline Microtus arvalis (common vole) & $\mathrm{T}(2)$ & $A(2)$ & (2) & $C(2)$ & $C(2)$ \\
\hline Lemmus trimucronatus (lemming) & $\mathrm{T}(1)$ & $A(1)$ & (1) & $C(1)$ & $C(1)$ \\
\hline Crossarchus alexandri (Alexander's cusimanse) & $A(1)$ & $A(1)$ & $A(1)$ & $A(1)$ & (1) \\
\hline Prionailurus bengalensis (leopard cat) & $A(1)$ & $A(1)$ & $A(1)$ & (1) & $A(1)$ \\
\hline Meles meles (European badger) & $C(1)$ & (1) & $C(1)$ & $C(1)$ & $C(1)$ \\
\hline Proteles cristatus (Aardwolf) & $C(1)$ & $A(1)$ & (1) & $A(1)$ & $A(1)$ \\
\hline Tapirus indicus (Malayan tapir) & $C(1)$ & $A(1)$ & $A(1)$ & $C(1)$ & (1) \\
\hline Cynopterus brachyotis (Lesser short-nosed fruit bat) & $C(1)$ & $A(1)$ & (1) & $C(1)$ & $A(1)$ \\
\hline Talpa stankovici (Balkan mole) & $C(1)$ & $A(1)$ & . (1) & $A(1)$ & $A(1)$ \\
\hline Dasypus novemcinctus (Nine-banded armadillo) & $C(1)$ & $A(1)$ & (1) & $C(1)$ & (1) \\
\hline Mystacina tuberculata (New Zealand lesser short-tailed bat) & $C(1)$ & (1) & $A(1)$ & $C(1)$ & $C(1)$ \\
\hline Oryctolagus cuniculus (European rabbit) & (1) & $A(1)$ & $C(1)$ & $C(1)$ & $\mathrm{T}(1)$ \\
\hline Arctogalidia trivirgata (Small-toothed palm civet) & $\mathrm{T}(1)$ & $A(1)$ & (1) & $A(1)$ & $A(1)$ \\
\hline Other mammals & $\mathrm{A} / \mathrm{C} / \mathrm{T}(281)$ & A (283) & $\mathrm{A} / \mathrm{C} / \mathrm{T}(280)$ & $\mathrm{A} / \mathrm{C} / \mathrm{T}(282)$ & $\mathrm{A} / \mathrm{C} / \mathrm{T}(283)$ \\
\hline
\end{tabular}

The number inside the bracket is the number of sequences showing the same nucleotide base from the same species.

$\because$ represents a nucleotide position showing the same nucleotide base as tiger.

a The position was determined by aligning these sequences with the cat sequences accession number U20753. 
SNPs, at positions 5050, 5533, 5608, 14618 , and 15743 , correspond to the only previously reported tiger subspecies-specific study [11]. In this previous report a further six subspecies-specific SNPs were recorded for the four tiger subspecies that we studied. However, these were not confirmed as subspecies-specific in our study as they were found in more than one subspecies.

Three hundred and forty-nine complete mammalian cyt $b$ sequences from 169 mammalian species were aligned with 71 tiger sequences to search for SNPs. A haplotype of the five SNPs was identified that is specific for all tiger subspecies and not present in other mammalian species. Four of these SNPs are multi-allelic markers, with only one SNP position (15268) being a bi-allelic transition. Even though some mammalian species exhibit the same nucleotide base as the tiger at a particular SNP, the tiger can be distinguished by the remaining SNPs. The SNPs and their position on the mitochondrial genome, including the lists of mammalian species providing the same nucleotide base as tiger species for each SNP, are shown in Table 4 . The positions of all eleven tiger species- and subspecies-specific SNPs are shown on a mitochondrial map (Fig. 1).

\subsection{SNaPshot multiplex assay for tiger species and its subspecies- specific SNPS}

The multiplex amplification using primer set P1, P2, and P3, which was designed to amplify mitochondrial regions surrounding all SNPs, was successfully performed on DNA samples of the four tiger subspecies. Each single subspecies sample provided the three expected PCR products of approximately 627, 656, and $683 \mathrm{bp}$ for each of the primers P1, P2, and P3. These PCR products were separated on a $3 \%$ agarose gel. The purified PCR products of these samples were then used as a SNaPshot template for a multiplex SNaPshot reaction in the subsequent analysis.

Each of the eleven extension primers was used in a SNaPshot reaction to extend the primers by one base, using the purified PCR product template. The expected nucleotide base, dye color and fragment sizes for these tiger species- and subspecies-specific SNPs are shown in Table 5 . The SNP typing for four tiger subspecies corresponded to the expected result, as shown in Fig. 2. It was noted that the observed peak size was slightly larger in mass than the

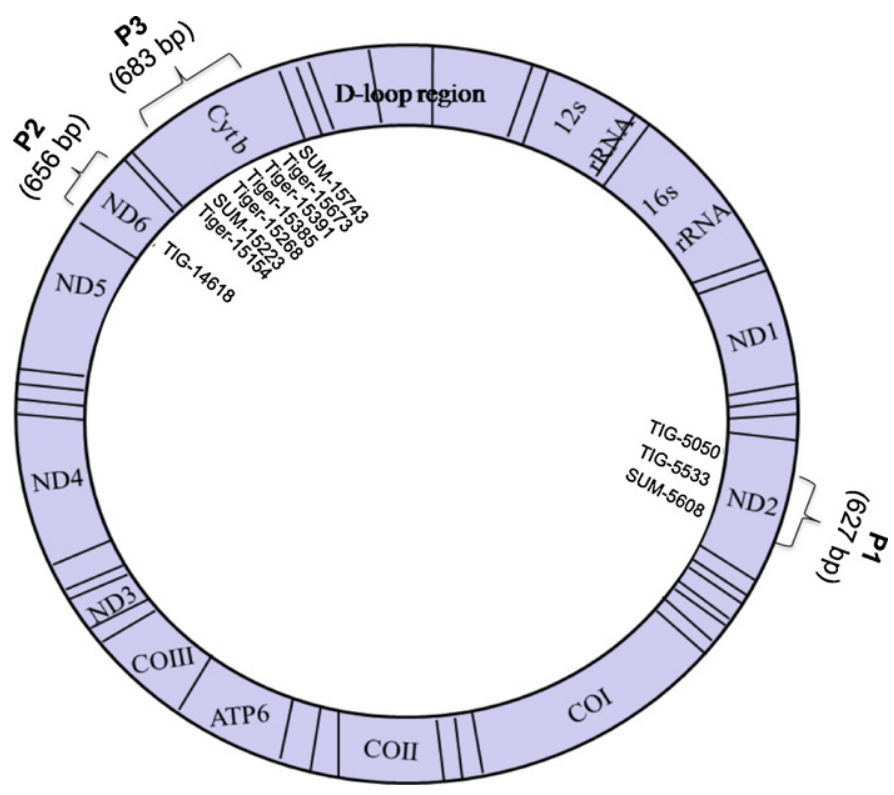

Fig. 1. The positions of all eleven tiger species- and subspecies-specific SNPs on the mitochondrial map. The SNPs are in the ND2, ND6 and cytochrome $b$ genes.

actual size for all SNPs; this was most likely due to the influence of the dye attached to the ddNTPs, thus increasing their mass and affecting fragment mobility in the capillary electrophoresis. The other factors causing mobility shift of SNaPshot products are the nucleotide composition and fragment size; the shorter the fragment size, the greater the impact of the fluorescent dye that occurs [36].

\subsection{SNaPshot assay validation}

\subsubsection{Accuracy test}

The precision of the assay was tested with 15 voucher tiger DNA samples. This resulted in a $100 \%$ level of accuracy. Each sample also showed the expected SNP typing as predicted for its reported subspecies. For all single SNPs the observed range of peak sizes and

Table 5

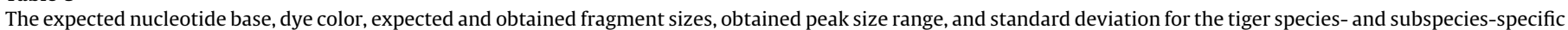
SNPs.

\begin{tabular}{|c|c|c|c|c|c|c|c|c|c|c|c|}
\hline \multirow{2}{*}{$\begin{array}{l}\text { Tiger } \\
\text { subspecies }\end{array}$} & $\begin{array}{l}\text { Tiger } \\
15154\end{array}$ & $\begin{array}{l}\text { Tiger } \\
15268\end{array}$ & $\begin{array}{l}\text { Tiger } \\
15385\end{array}$ & $\begin{array}{l}\text { Tiger } \\
15391\end{array}$ & $\begin{array}{l}\text { Tiger } \\
15673\end{array}$ & $\begin{array}{l}\text { TIG } \\
5050\end{array}$ & $\begin{array}{l}\text { TIG } \\
5533\end{array}$ & $\begin{array}{l}\text { TIG } \\
14618\end{array}$ & $\begin{array}{l}\text { SUM } \\
5608\end{array}$ & $\begin{array}{l}\text { SUM } \\
15223\end{array}$ & $\begin{array}{l}\text { SUM } \\
15743\end{array}$ \\
\hline & B & B & B & B & B & B & B & B & B & B & B \\
\hline P.t. tigris & G & $\mathrm{C}$ & $\mathrm{C}$ & G & G & $\mathrm{T}$ & A & $\mathrm{T}$ & G & $\mathrm{T}$ & $\mathrm{T}$ \\
\hline P.t. sumatrae & G & $\mathrm{C}$ & $\mathrm{C}$ & G & G & $\mathrm{C}$ & G & $\mathrm{C}$ & A & A & $\mathrm{C}$ \\
\hline P.t. corbetti & G & $\mathrm{C}$ & $\mathrm{C}$ & G & G & C & G & $\mathrm{C}$ & G & $\mathrm{T}$ & $\mathrm{T}$ \\
\hline P. t. altaica & G & $\mathrm{C}$ & $\mathrm{C}$ & G & G & C & G & C & G & $\mathrm{T}$ & $\mathrm{T}$ \\
\hline $\begin{array}{l}\text { Expected peak } \\
\text { size }\end{array}$ & 20 & 25 & 30 & 35 & 40 & 45 & 50 & 55 & 60 & 65 & 70 \\
\hline $\begin{array}{l}\text { Observed peak } \\
\text { size average }\end{array}$ & 30.11 & 32.04 & 34.27 & 39.78 & 44.52 & 48.58 & 53.06 & 57.87 & 64.72 & 68.66 & 75.54 \\
\hline $\begin{array}{l}\text { Observed peak } \\
\text { size-range }(n=10)\end{array}$ & $\begin{array}{l}29.53- \\
30.81\end{array}$ & $\begin{array}{l}31.57- \\
32.66\end{array}$ & $\begin{array}{l}33.91- \\
34.64\end{array}$ & $\begin{array}{l}39.51- \\
40.13\end{array}$ & $\begin{array}{l}44.27- \\
44.87\end{array}$ & $\begin{array}{l}47.97- \\
49.62\end{array}$ & $\begin{array}{l}52.22- \\
54.50\end{array}$ & $\begin{array}{l}57.46- \\
58.83\end{array}$ & $\begin{array}{l}64.23- \\
65.57\end{array}$ & $\begin{array}{l}68.04- \\
69.11\end{array}$ & $\begin{array}{l}73.58- \\
76.23\end{array}$ \\
\hline $\operatorname{STD}(n=10)$ & 0.39 & 0.31 & 0.22 & 0.19 & 0.18 & 0.37 & 0.55 & 0.38 & 0.40 & 0.31 & 0.54 \\
\hline
\end{tabular}

$\mathrm{B}$ is nucleotide base/C is color. 


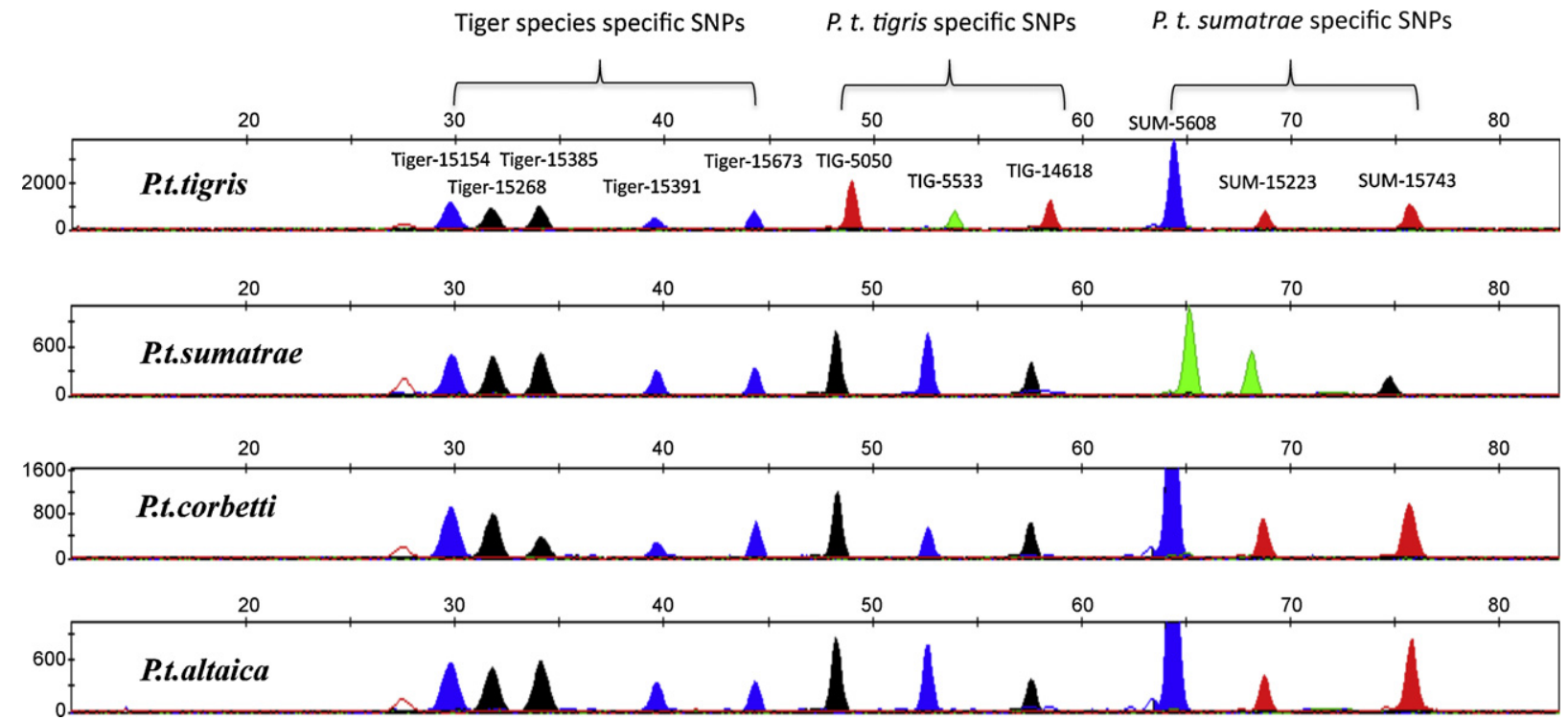

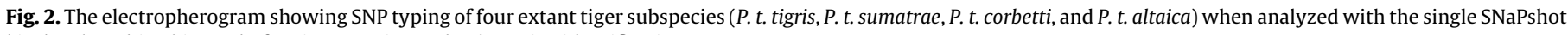
kit developed in this study for tiger species and subspecies identification.

standard deviations were calculated as shown in Table 5. The standard deviations of the observed fragment size are in the range of $0.18-0.55$. The lowest values of standard deviation were found in the tiger species-specific SNPs of Tiger-15673 and Tiger-15391. Conversely, two of the tiger subspecies-specific SNPs, TIG-5533 and SUM-15743, reported the highest standard deviation, owing to the significant difference in fragment size between those for the species-specific assays and those for other tiger subspecies. However, this difference was still less than one base pair.

\subsubsection{Sensitivity test}

The sensitivity of the assay was determined by preparing five DNA concentrations from a two-fold serial dilution containing quantified tiger DNA. A full SNP profile can be obtained from as little as 15,000 copies of target mitochondrial DNA (equating to $0.26 \mathrm{pg}$ ), indicating that the test will work on trace amounts of tissue or hair samples. The PCR product amplified from this sample was also the lowest concentration of starting template from which a PCR product could be observed on an agarose gel when stained with ethidium bromide. The presence of an amplification product acted as a rapid screening test to indicate the potential success in obtaining a full SNP profile.

\subsubsection{Specificity test}

One tiger and fourteen mammalian samples were tested to determine the specificity of the assay. A full SNP profile was retrieved only for $P$. tigris, indicating that the developed assay is specific to this species. However, DNA from other cat species was also successfully amplified by P1, P2 and P3, including cheetah, jaguar, lion, leopard, snow leopard, clouded leopard, puma and domestic cat. All three expected multiplex PCR fragments were generated by the tiger sample as predicted. The band patterns and the intensities obtained for the cat species were different to those for the tiger samples as shown in Fig. 3.

A SNP specificity test was performed using 14 mammalian species, including closely related Panthera species, none of which produced products at the same positions as tiger SNPs; this new SNP test has the potential to identify other big cat species.

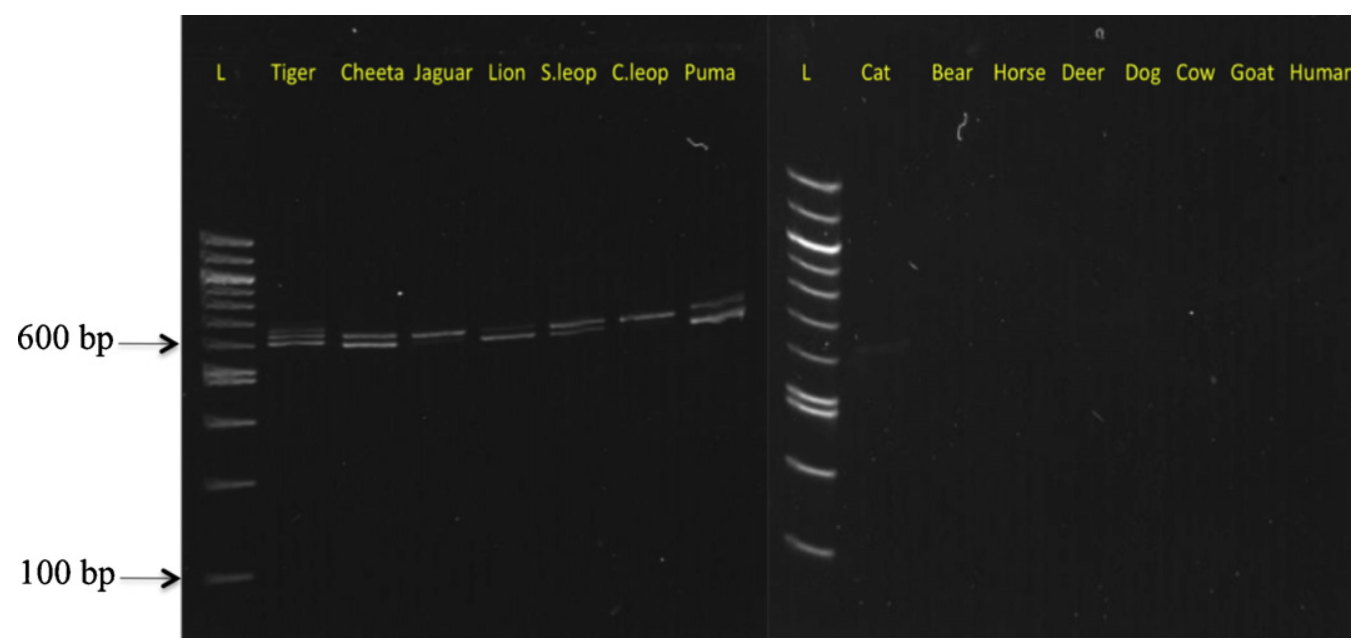

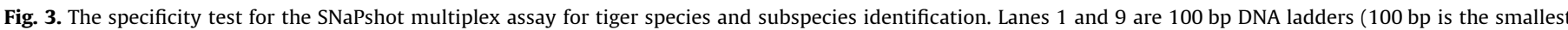

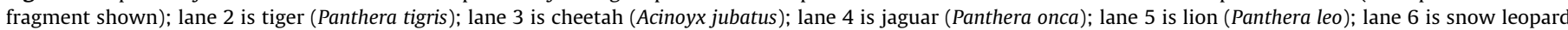

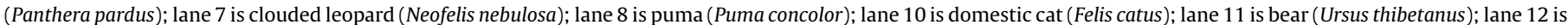

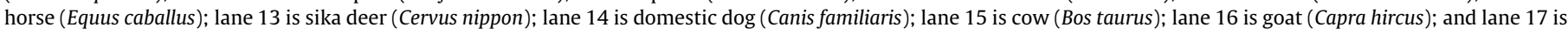
human (Homo sapiens). The PCR products ( $10 \mu \mathrm{L} /$ well) were separated on a $3 \%$ agarose gel and visualized with ethidium bromide staining. 
Table 6

The result of blind trial testing in 10 DNA sample picked at random.

\begin{tabular}{|c|c|c|c|c|c|c|c|c|c|c|}
\hline \multirow[t]{2}{*}{ Result } & \multicolumn{10}{|c|}{ Sample no. } \\
\hline & 1 & 2 & 3 & 4 & 5 & 6 & 7 & 8 & 9 & 10 \\
\hline Observed result & Other & $\begin{array}{l}\text { Tiger } \\
\text { P.t. tigris }\end{array}$ & Big cat & Big cat & $\begin{array}{l}\text { Tiger } \\
\text { P.t. tigris }\end{array}$ & $\begin{array}{l}\text { Tiger } \\
\text { P.t. corbetti }\end{array}$ & Other & $\begin{array}{l}\text { Tiger } \\
\text { P.t. tigris }\end{array}$ & Other & $\begin{array}{l}\text { Tiger } \\
\text { P.t. altaica }\end{array}$ \\
\hline DNA source & Lamp & $\begin{array}{l}\text { Tiger } \\
\text { P.t. tigris }\end{array}$ & Jaguar & Puma & $\begin{array}{l}\text { Tiger } \\
\text { P.t. tigris }\end{array}$ & $\begin{array}{l}\text { Tiger } \\
\text { P.t. corbetti }\end{array}$ & Horse & $\begin{array}{l}\text { Tiger } \\
\text { P.t. tigris }\end{array}$ & Fox & $\begin{array}{l}\text { Tiger } \\
\text { P.t. altaica }\end{array}$ \\
\hline Correct & $\nu$ & $\nu$ & $\nu$ & $\nu$ & $\nu$ & & & $\nu$ & $\nu$ & $\nu$ \\
\hline
\end{tabular}

\subsubsection{Blind-trial test}

Random single blind trials were performed to examine the SNaPshot multiplex effectiveness of the assay. Ten DNA samples were picked at random and amplified by the multiplex primers and run on a $3 \%$ agarose gel. Eight of ten samples were successfully amplified as noted by gel electrophoresis. The two samples that were not successfully amplified were identified as samples from other mammalian species, but were neither tiger nor other big cat species. The eight samples that were amplified successfully were then analyzed by SNaPshot multiplex assay. Of these samples, five provided full SNP typing as predicted if they were one of the tiger subspecies; this was later confirmed. The samples that showed no SNP peaks were later identified as a big cat species, other than tiger, again as predicted by the SNP testing. The blind-trial results for all samples revealed $100 \%$ accuracy when categorizing unknown samples into one of the three categories: tiger, other big cats, and other mammalian species, as shown in Table 6 .

\section{Conclusion}

A common approach to species identification, using molecular methods, is to sequence a mitochondrial gene locus such as cyt $b$ or $\mathrm{COI}$; or to use species-specific primers [37]. In the case of subspecies identification, there are only a few signature bases that differentiate such closely related taxa. In the entire tiger mitochondrial genome, with a range of approximately $17,000 \mathrm{bp}$, only six SNP bases were identified that could distinguish between subspecies. Within the cyt $b$ gene, one of the most commonly used gene loci in species identification [38], there were only five SNPs of value that separate any subspecies of $P$. tigris from other mammals. The development of a SNP test to identify these bases circumvents generating long DNA sequences that are of little or no diagnostic value. Further, the multiplex SNP assay allows SNPs from more than one gene to be identified in one reaction. We were able to identify and validate eleven tiger species- and subspecies-specific SNPs, spanning the entire tiger mitochondrial genome. The single SNaPshot multiplex assay developed to detect these SNPs was found to be reliable, accurate, specific, sensitive and robust. The assay will prove to be useful in forensic applications as it is able to detect and identify tiger species and subspecies in trace or degraded biological evidence.

\section{Acknowledgements}

The authors gratefully acknowledge the support of the South Australia Ministry of Justice, the Leverhulme Trust, and the Royal Thai Government for funding AL, SST, and TK, respectively. We would also like to thank the Dudley Zoo, Isle of Wight Zoo, Edinburgh Zoo, National Museums Scotland and Auchingarrich Wildlife Park for the contribution of species samples.

\section{Appendix A. Supplementary data}

Supplementary data associated with this article can be found, in the online version, at doi:10.1016/j.fsigen.2011.06.001.

\section{References}

[1] J. Wentzel, J.C. Stephens, W. Johnson, M.M. Raymond, J.P. Slattery, Subspecies of tigers: molecular assessment using "voucher specimens" of geographically traceable individuals, in: J. Seidensticker, S. Christie, P. Jackson (Eds.), Riding the Tiger: Tiger Conservation in Human-Dominated Landscapes, Cambridge University Press, Cambridge, 1999, pp. 40-49.

[2] R.L. Tilson, U.S. Seal, Tigers of the World. The Biology, Biopolitics, Management, and Conservation of an Endangered Species, Noyes Publications, New Jersey, 1987

[3] K. Nowell, P. Jackson, Wild Cats: Status Survey and Conservation Action Plan, IUCN, Gland, Switzerland, 1996.

[4] V. Morell, Wildlife biology: can the wild tiger survive? Science 317 (2007) 1312-1314.

[5] J. Seidensticker, B. Gratwicke, M. Shrestha, How many wild tigers are there? An estimate for 2008, in: T. Ronald, J.N. Philip (Eds.), Tigers of the World, second ed., William Andrew Publishing, Boston, 2010, pp. 295-299.

[6] S.J. Luo, W.E. Johnson, J. Martenson, A. Antunes, P. Martelli, O. Uphyrkina, K.T. Holzer, J.L. Smith, S.J. O’Brien, Subspecies genetic assignments of worldwide captive tigers increase conservation value of captive populations, Curr. Biol. 18 (2008) 592-596.

[7] K. Sankhala, Tiger! Story of the Indian Tiger, Collins, New York, 1977.

[8] V.G. Heptner, A.A. Sludskii, Mammals of the Soviet Union Volume II, Part 2 Carnivora (Hyaenas and Cats), Smithsonian Institution Libraries and the National Science Foundation, Washington, DC, 1992.

[9] V. Mazák, Panthera tigris, Mamm. Species 152 (1981) 1-8.

[10] Y. Xu, S. Fang, Z. Li, Sustainability of the South China tiger: implications of inbreeding depression and introgression, Conserv. Genet. 8 (2007) 1199-1207.

[11] S.J. Luo, J.H. Kim, W.E. Johnson, J. Van Der Walt, J. Martenson, N. Yuhki, D.G. Miquelle, O. Uphyrkina, J.M. Goodrich, H.B. Quigley, R. Tilson, G. Brady, P. Martelli, V. Subramaniam, C. Mcdougal, S. Hean, S.Q. Huang, W. Pan, U.K. Karanth, M. Sunquist, J.L. Smith, S.J. O'Brien, Phylogeography and genetic ancestry of tigers (Panthera tigris), PLoS Biol. 2 (2004) e442.

[12] J.H. Mazák, Craniometric variation in the tiger (Panthera tigris): implications for patterns of diversity, taxonomy and conservation, Mamm. Biol.: Z. Saugetierkd. 75 (2010) 45-68.

[13] J. Cracraft, J. Feinstein, J. Vaughn, K. Helm-Bychowski, Sorting out tigers (Panthera tigris): mitochondrial sequences, nuclear inserts, systematics, and conservation genetics, Anim. Conserv. 1 (1998) 139-150.

[14] A.C. Kitchener, Tiger distribution, phenotypic variation and conservation issues, in: J. Seidensticker, S. Christie, P. Jackson (Eds.), Riding the Tiger: Tiger Conservation in Human-Dominated Landscapes, Cambridge University Press, Cambridge, 1999.

[15] S.M. Barber-Meyer, Dealing with the Clandestine nature of wildlife-trade market surveys Haciendo Frente a la Naturaleza Clandestina de los Estudios de Mercado del Comercio de Vida Silvestre, Conserv. Biol. 24 (2010) 918-923.

[16] L.S. Wyler, P.A. Sheikh, International Illegal Trade in Wildlife: Threats and U.S. Policy, 2008 Available from: http://opencrs.com/document/RL34395/ (accessed 18 February 2011).

[17] K. Nowell, X. Ling, Taming the Tiger Trade: China's Markets for Wild and Captive Tiger Products Since the 1993 Domestic Tiger Trade Ban, 2007 Available from: http://www.worldwildlife.org/what/globalmarkets/wildlifetrade/chinatigertrade/ index.html (accessed 18 February 2011).

[18] E. Dinerstein, C. Loucks, E. Wikramanayake, J. Ginsberg, E. Sanderson, J. Seidensticker, J. Forrest, G. Bryja, A. Heydlauff, S. Klenzendorf, P. Leimgruber, J. Mills, T.G. O'brien, M. Shrestha, R. Simons, M. Songer, The fate of wild tigers, BioScience 57 (2009) 508-514.

[19] C.R. Shepherd, N.D. Magnus, Nowhere to Hide: The Trade in Sumatran Tiger, 2004 Available from: http://www.traffic.org/southeast-asia/ (accessed 18 February 2011).

[20] D.G. Rowe, China and Its Friends Push Tiger Farm Idea. The New Scientist, 2006 Available from: http://www.newscientist.com/article/dn10603-china-and-itsfriends-push-tiger-farm-idea.html (accessed 18 February 2011)

[21] G. Hemley, J.A. Mills, The beginning of the end of tigers in trade? in: J. Seidensticker, S. Christie, P. Jackson (Eds.), Riding the Tiger: Tiger Conservation in Human-Dominated Landscapes, Cambridge University Press, 1999, pp. 217-222.

[22] J.A. Mills, P. Jackson (Eds.), Killed for a Cure: A Review of the Worldwide Trade in Tiger Bone, Traffic International, Cambridge, 1994.

[23] B. Wright, Will the tiger survive in India? in: T. Ronald, J.N. Philip (Eds.), Tigers of the World, second ed., William Andrew Publishing, Boston, 2010, pp. 87-100. 
[24] A.C. Kitchener, N. Yamaguchi, What is a tiger? Biogeography, morphology, and taxonomy, in: T. Ronald, J.N. Philip (Eds.), Tigers of the World, second ed., William Andrew Publishing, Boston, 2010, pp. 53-84

[25] Q.H. Wan, S.G. Fang, Application of species-specific polymerase chain reaction in the forensic identification of tiger species, Forensic Sci. Int. 131 (2003) 75-78.

[26] N. Mukherjee, S. Mondol, A. Andheria, U. Ramakrishnan, Rapid multiplex PCR based species identification of wild tigers using non-invasive samples, Conserv. Genet. 8 (2007) 1465-1470.

[27] A. Linacre, S.S. Tobe, On the trial of tigers-tracking tiger in Traditional East Asian Medicine, Forensic Sci. Int. Genet. Suppl. Ser. 1 (2008) 603-604.

[28] S. Mukherjee, A. Cn, C. Home, U. Ramakrishnan, An evaluation of the PCR-RFLP technique to aid molecular-based monitoring of felids and canids in India, BMC Res. Notes 3 (2010) 159.

[29] J.H. Wetton, C.S.F. Tsang, C.A. Roney, A.C. Spriggs, An extremely sensitive speciesspecific ARMS PCR test for the presence of tiger bone DNA, Forensic Sci. Int. 126 (2002) 137-144.

[30] J. Lee, H.-M. Hsieh, L.-H. Huang, Y.-C. Kuo, J.-H. Wu, S.-C. Chin, A.-H. Lee, A. Linacre, L.-C. Tsai, Ivory identification by DNA profiling of cytochrome b gene, Int. J. Legal Med. 123 (2009) 117-121.

[31] S.K. Verma, L. Singh, Novel universal primers establish identity of an enormous number of animal species for forensic application, Mol. Ecol. Notes 3 (2003) 28-31.
[32] R. Ogden, H.N. Mcgough, R.S. Cowan, L. Chua, M. Groves, R. Mcewing, SNP-based method for the genetic identification of ramin Gonystylus spp. timber and products: applied research meeting CITES enforcement needs, Endangered Species Res. 9 (2008) 255-261.

[33] M.A. Larkin, G. Blackshields, N.P. Brown, R. Chenna, P.A. Mcgettigan, H. Mcwilliam, F. Valentin, I.M. Wallace, A. Wilm, R. Lopez, J.D. Thompson, T.J. Gibson, D.G. Higgins, Clustal W and Clustal X version 2.0, Bioinformatics 23 (2007) 2947-2948.

[34] T. Kitpipit, A. Linacre, S.S. Tobe, Tiger species identification based on molecular approach, Forensic Sci. Int. Genet. Suppl. Ser. 2 (2009) 310-312.

[35] S.S. Tobe, A.M.T. Linacre, A technique for the quantification of human and nonhuman mammalian mitochondrial DNA copy number in forensic and other mixtures, Forensic Sci. Int. Genet. 2 (2008) 249-256.

[36] D. Huang, C. Gui, S. Yi, Q. Yang, R. Yang, K. Mei, Typing of $24 \mathrm{mtDNA}$ SNPs in a Chinese population using SNaPshot minisequencing, J. Huazhong Univ. Sci. Technol.: Med. Sci. 30 (2010) 291-298.

[37] S. Tobe, A. Linacre, DNA typing in wildlife crime: recent developments in species identification, Forensic Sci. Med. Pathol. 6 (2010) 195-206.

[38] S.S. Tobe, A.C. Kitchener, A.M.T. Linacre, Reconstructing mammalian phylogenies: a detailed comparison of the cytochrome and cytochrome oxidase subunit mitochondrial genes, PLoS ONE 5 (2010) e14156. 